\title{
Mechanisms of Cellular Effects Directly Induced by Magnetic Nanoparticles under Magnetic Fields
}

\author{
Linjie Chen, ${ }^{1,2,3}$ Changyou Chen, ${ }^{1,3}$ Pingping Wang, ${ }^{1,3}$ and Tao Song ${ }^{1,2,3}$ \\ ${ }^{1}$ Beijing Key Laboratory of Bioelectromagnetism, Institute of Electrical Engineering, Chinese Academy of Sciences, Beijing, China \\ ${ }^{2}$ University of Chinese Academy of Sciences, Beijing, China \\ ${ }^{3}$ France-China Bio-Mineralization and Nano-Structures Laboratory, Beijing, China
}

Correspondence should be addressed to Tao Song; songtao@mail.iee.ac.cn

Received 13 February 2017; Revised 6 April 2017; Accepted 26 April 2017; Published 13 June 2017

Academic Editor: Paulo Cesar Morais

Copyright (C) 2017 Linjie Chen et al. This is an open access article distributed under the Creative Commons Attribution License, which permits unrestricted use, distribution, and reproduction in any medium, provided the original work is properly cited.

\begin{abstract}
The interaction of magnetic nanoparticles (MNPs) with various magnetic fields could directly induce cellular effects. Many scattered investigations have got involved in these cellular effects, analyzed their relative mechanisms, and extended their biomedical uses in magnetic hyperthermia and cell regulation. This review reports these cellular effects and their important applications in biomedical area. More importantly, we highlight the underlying mechanisms behind these direct cellular effects in the review from the thermal energy and mechanical force. Recently, some physical analyses showed that the mechanisms of heat and mechanical force in cellular effects are controversial. Although the physical principle plays an important role in these cellular effects, some chemical reactions such as free radical reaction also existed in the interaction of MNPs with magnetic fields, which provides the possible explanation for the current controversy. It is anticipated that the review here could provide readers with a deeper understanding of mechanisms of how MNPs contribute to the direct cellular effects and thus their biomedical applications under various magnetic fields.
\end{abstract}

\section{Introduction}

With the explosive development of nanotechnology, multifarious nanomaterials emerge quickly. As a typical nanomaterial, magnetic nanoparticles (MNPs) mainly contain nanoparticles of magnetite $\left(\mathrm{Fe}_{3} \mathrm{O}_{4}\right)$ and maghemite $\left(\gamma-\mathrm{Fe}_{2} \mathrm{O}_{3}\right)$, their dopant compound $\left(\mathrm{MFe}_{2} \mathrm{O}_{4}\right.$, where $\mathrm{M}=\mathrm{Mn}, \mathrm{Co}, \mathrm{Zn}$, etc.), and intermetallic system (e.g., $\mathrm{Nd}_{2} \mathrm{Fe}_{14} \mathrm{~B}, \mathrm{SmCo}_{5}$ ) $[1,2]$. MNPs display their size within dozens to hundreds of nanometers and have a high specific surface area. As magnetic materials, MNPs possess the outstanding properties of magnetism, which can be affected by external magnetic fields. Generally, MNPs are synthesized chemically [3] and further decorated by molecules like polyethylenimine [4], folic acid [5], chitosan oligosaccharide [6], epidermal growth factor receptor [7], antibodies [8, 9], and so on. In addition to this, some biological magnetic nanoparticles also receive considerable attention, such as magnetosome, a particular kind of $\mathrm{Fe}_{3} \mathrm{O}_{4}$ or $\mathrm{Fe}_{3} \mathrm{~S}_{4}$ nanocrystal covered by biological membrane which is formed by magnetotactic bacteria [10-12].
Due to versatile intrinsic properties, MNPs including magnetosomes have promoted challenging innovations in biomedical application through their interplay with various magnetic fields. In combination with magnetic resonance imaging, MNPs are a fairly effective medical imaging contrast agent [13]. MNPs are also used as drug carrier in targeted therapy $[14,15]$ and are designed to be biosensors $[14,16]$. As an indispensable tool, MNPs play an important role in those applications. During the applications, an external magnetic field is usually required. In addition, MNPs could directly induce the cell effects under magnetic fields. For instance, when exposed to an alternating magnetic field (AMF) MNPs are able to be used to kill tumor cells [17-19]. Recently, it has been described that the interaction of MNPs and a magnetic field induced mechanical force which is directly applied for cell regulation [20,21].

With such issues in mind, here in this review, we try to present a brief summary of cellular effects directly induced by the interaction of MNPs with magnetic fields. We describe 
cellular effects of heat generated by MNPs under an alternating magnetic field. Besides the heat effects, this review also addresses direct effects of mechanical force on cell status utilizing MNPs in a magnetic field. Finally, we discuss cellular effects of MNPs under magnetic fields from the point of view of free radicals. The related mechanisms behind these cellular effects are simultaneously elaborated.

\section{Effect of Heat}

When interplaying with a high frequency magnetic field, MNPs transform field energy into heat through the mechanisms of magnetic hysteresis, Néel or Brown relaxation, and eddy current effect [22-24]. Generally, the temperature induced by the technology must increase to $42^{\circ} \mathrm{C}$ at least to harm needless cells $[25,26]$. The heat effect that resulted from MNPs in a high frequency magnetic field is also called magnetic hyperthermia which could be used in biomedical therapy [27]. For example, cancer is an important treatment target of magnetic hyperthermia since cancerous cells are more sensitive to heat than normal ones $[28,29]$.

\subsection{High Doses of MNPs in an Alternating Magnetic Field}

2.1.1. Artificially Synthesized MNPs. Common magnetic hyperthermia generally used high doses of MNPs to contact with cancer cells and simply injected them into an intratumoral space and then applied a high frequency magnetic field (usually used in the range of $100-300 \mathrm{kHz}$ and $5-40 \mathrm{kA} / \mathrm{m}$ ) or radio-wave magnetic field to induce the increase of temperature for killing cancer cells. Sadhukha et al. observed the elimination of cancer stem cells in vitro using MNPs of $12 \mathrm{~nm}$ in diameter under an alternating magnetic field (6 kA/ $\mathrm{m}, 366 \mathrm{kHz}, 10 \mathrm{~min}$ ) [30]. As for in vivo hyperthermia treatment, some studies also used high doses of antibody-coated MNPs to target tumor tissue. Balivada et al. used bimagnetic $\mathrm{Fe} / \mathrm{Fe}_{3} \mathrm{O}_{4}$ core/shell nanoparticles for cancer targeting and therapy in vivo after intratumoral or intravenous administration under the AMF $(5 \mathrm{kA} / \mathrm{m}, 366 \mathrm{kHz}, 10 \mathrm{~min})$ and found that the temperature in tumor site increased by $11^{\circ} \mathrm{C}$ and that the tumor size decreased [31]. Ota et al. showed that antiFas antibody-conjugated MNPs decreased HeLa cell viability more significantly than bare MNPs under an AMF $(20 \mathrm{kA} /$ $\mathrm{m}, 210 \mathrm{kHz}, 60 \mathrm{~min}$ ) [32]. Compared to chemotherapy and radiotherapy, common magnetic hyperthermia using high doses of MNPs would not induce damage of whole body, suggesting that the heat effect directly induced by MNPs under an AMF has the potential to treat cancer. But high doses of MNPs directly injected in tumor and used in common magnetic hyperthermia still cannot target deep location in a noninvasive way. Here we also reviewed other studies regarding the in vitro and in vivo application of MNPs at high doses under an AMF (Table 1).

While the in vitro and in vivo studies were performed broadly, several articles reported the clinical trials done on patients using magnetic hyperthermia. Maier-Hauff et al. prepared preclinical trials on 14 patients suffering from recurrent glioblastoma multiforme (GBM) by using aminosilanecoated MNPs under an AMF $(2.5-18 \mathrm{kA} / \mathrm{m}, 100 \mathrm{kHz})$ and found that the intratumoral temperature increased to an average of $44.6^{\circ} \mathrm{C}$, which could control local tumor [54]. Later, Maier-Hauff et al. continued performing a clinical study on 59 patients with GBM by neuronavigationally controlling intratumoral instillation of an aqueous dispersion of iron oxide (magnetite) nanoparticles and exposing it to an alternating magnetic field $(0-18 \mathrm{kA} / \mathrm{m}, 100 \mathrm{kHz})$ in combination with radiotherapy [55]. The results of this study showed that the combination therapeutics increased the overall survival of patients. Other preclinical trials are carried out on prostate cancer. Johannsen et al. presented the first clinical application of interstitial hyperthermia $(2.5-18 \mathrm{kA} / \mathrm{m}, 100 \mathrm{kHz})$ using MNPs in locally recurrent prostate cancer and demonstrated that interstitial deposition of MNPs within the prostate cancer is stable for several weeks, making sequential hyperthermia treatments possible without the need for repeated injection of magnetic fluid into the prostate [56]. Then they found that thermoablative temperatures could be achieved in the trails on 10 patients with locally recurrent prostate cancer using magnetic hyperthermia, making hyperthermia treatments feasible. Although the clinical trials were done by using magnetic hyperthermia, adverse effects are brought to attention. The high temperature may damage adjacent tissues and induce detrimental impact on tissue metabolism, blood flow, organ function, tissue repair, and so on. Higher magnetic field strengths and irregular intratumoral heat distribution may cause the malaise of patients, especially GBM patients.

Currently, the heat effect caused by MNPs under an AMF has showed its application against the diseases of infection caused by pathogens, especially drug-resistant microbe. Kim et al. showed that MNPs which were conjugated with antiProtein A antibody were able to target Staphylococcus aureus (S. aureus) and could kill the pathogen both in vitro and in vivo under an AMF (31 kA/m, 2.1 MHz, $3 \mathrm{~min})$ [57]. Rodrigues et al. used polyacrylic acid coated $\mathrm{Fe}_{3} \mathrm{O}_{4} \mathrm{MNPs}$ to evaluate the effect of magnetic hyperthermia $(8 \mathrm{kA} / \mathrm{m}$, $873 \mathrm{kHz}$ ) on planktonic cells and biofilms of a major food spoilage bacterium Pseudomonas fluorescens and found that the hyperthermia was harmful to the integrity of cell membranes and reduced the cell viability significantly [58].

2.1.2. Magnetosome. Apart from artificially produced MNPs used in magnetic hyperthermia for killing tumor or pathogenic cells among in vitro and in vivo studies and in clinical trials, magnetosomes are also employed to kill cancer cells under an AMF. Magnetosomes could be modified easily due to their biological membrane and have the features of single magnetic domain and good biocompatibility. Hergt et al. reported that specific loss power of magnetosomes at an applied AMF of $410 \mathrm{kHz}$ and field amplitude $10 \mathrm{kA} / \mathrm{m}$ could reach $960 \mathrm{~W} / \mathrm{g}$, higher than that of the chemically synthesized nanoparticles [59]. Liu et al. showed that when MCF-7 tumor cells were mixed with bacterial magnetosomes and then exposed to an $\mathrm{AMF}(8.8 \mathrm{kA} / \mathrm{m}, 300 \mathrm{kHz})$ for $2 \mathrm{~min}$, temperature reached $47^{\circ} \mathrm{C}$ and $80 \%$ of the cell proliferation was inhibited [60]. Mannucci et al. directly injected magnetosomes into subcutaneous tumors in mice and found that administration of an AMF $(23 \mathrm{kA} / \mathrm{m}, 187 \mathrm{kHz})$ induced fibrous and necrotic 


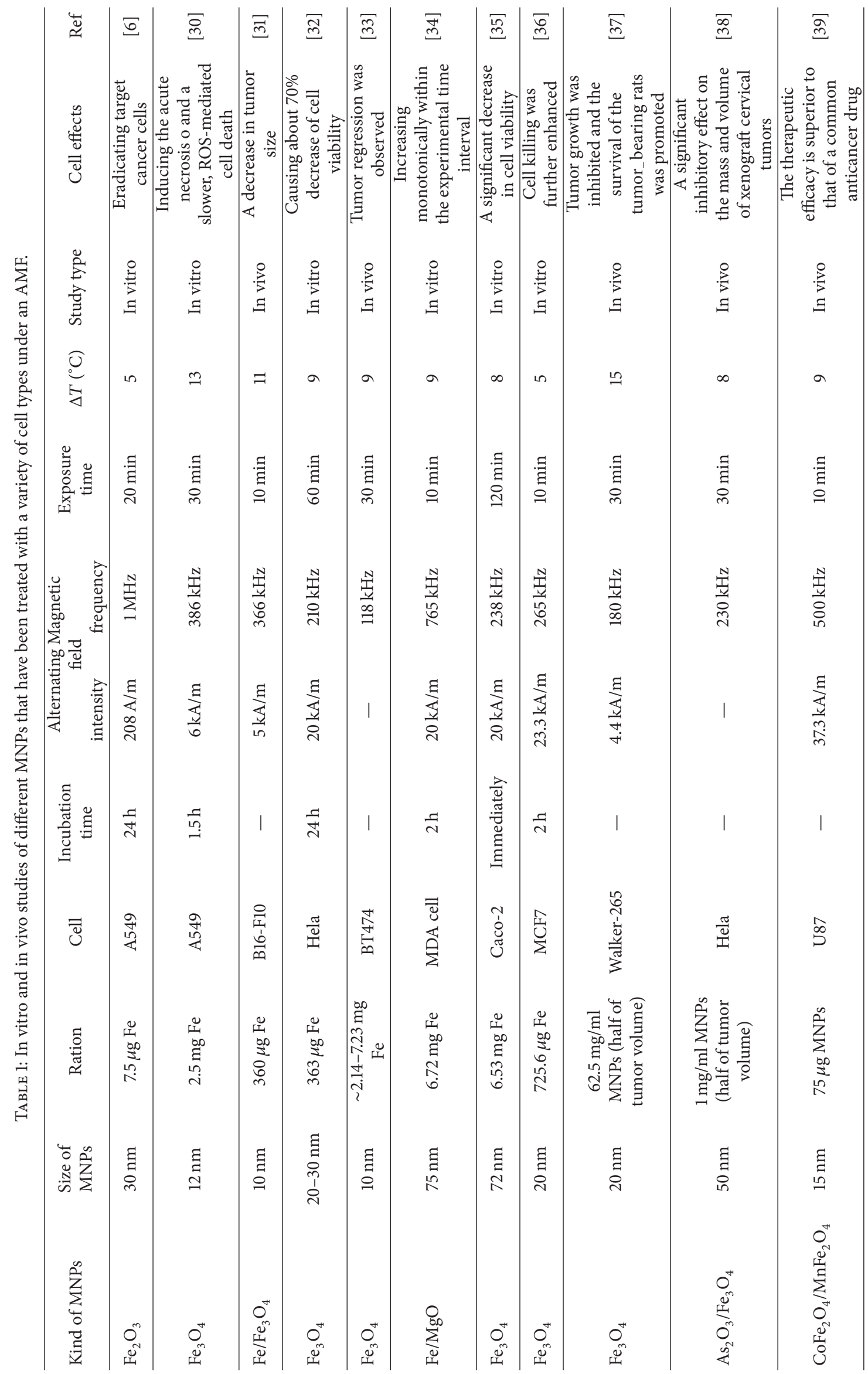




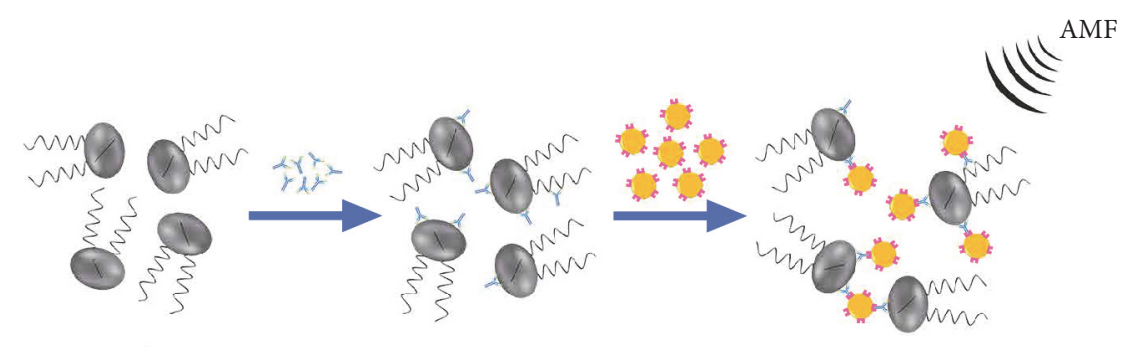

Magnetotactic bacteria MO-1

Staphylococcus aureus

Rabbit anti-MO-1 polyclonal antibody

II Protein A

(a)

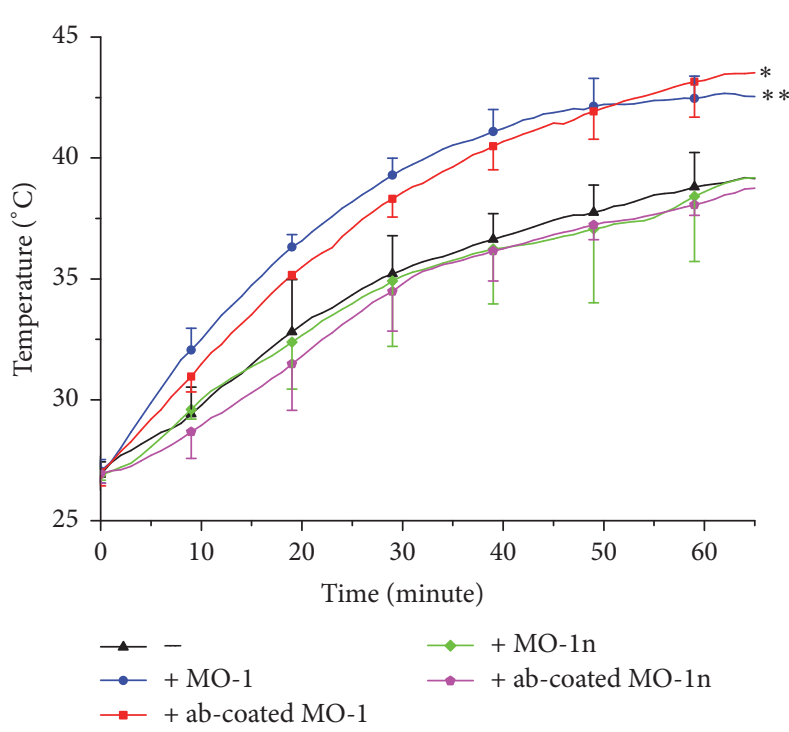

(b)

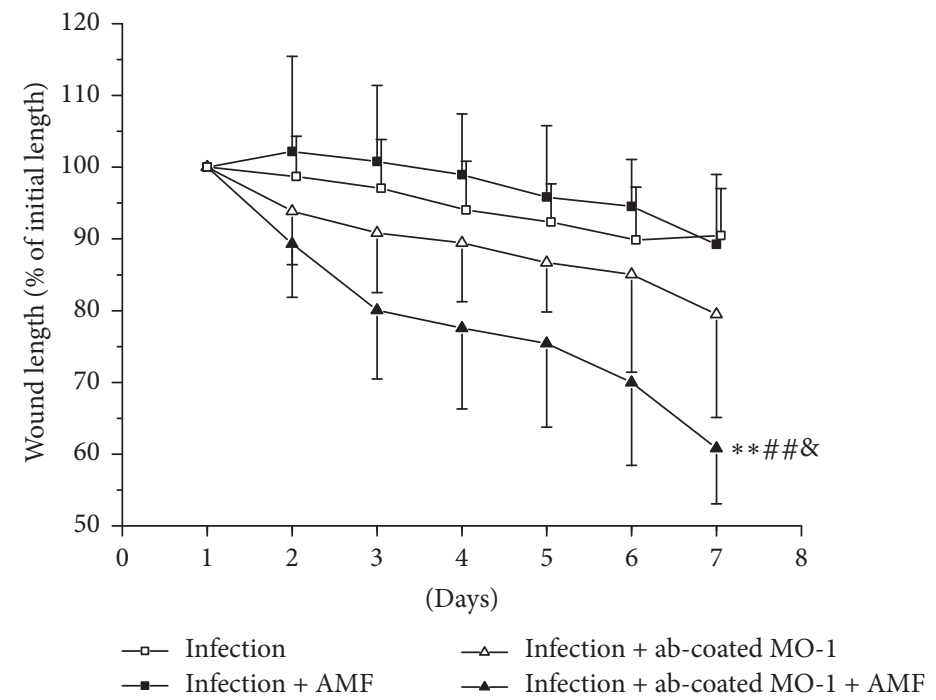

(c)

FIGURE 1: Magnetotactic bacteria-mediated magnetic hyperthermia for killing of S. aureus [64]. (a) The schematic representation of magnetotactic-bacterium-mediated magnetic hyperthermia. (b) The temperature rise under an alternating magnetic field. MO- $1 \mathrm{n}$ notes MO-1 cells without magnetosomes. (c) The healing effect of the S. aureus-infected wound by MO-1-mediated magnetic hyperthermia. In Figure 1(b), $*$ refers to $P<0.05$ and $* *$ refers to $P<0.01$ versus the suspension of $S$. aureus alone (triangle line). In Figure $1(\mathrm{c}), * *$ refers to $P<0.01$ (versus infection-only group); \#\# refers to $P<0.01$ (versus infection+AMF group); \& refers to $P<0.05$ (versus infection + ab-coated MO-1 group).

areas close to the injection sites in mice [61]. Alphandéry et al. used $\sim 1 \mathrm{mg}$ chains of magnetosomes to eradicate a tumor xenografted under the skin of a mouse after being exposed to an AMF $(32 \mathrm{kA} / \mathrm{m}, 183 \mathrm{kHz})$ for three heat cycles of $20 \mathrm{~min}$, during which the tumor temperature was raised to $\sim 43^{\circ} \mathrm{C}$, and further found that the antitumor effect using chains of magnetosomes is higher than that using individual magnetosomes or chemically synthesized MNPs [62]. Later, Alphandéry et al. speculated that chains of magnetosomes were not easy to be aggregated and may generate mechanical force that damages the cells under the magnetic field after conjugating with the cell membrane [63].

Magnetotactic bacteria were also applied to combat $S$. aureus-induced skin infection under an alternating magnetic field by Chen et al. [64]. Antibody-coated magnetotactic bacteria could target $S$. aureus because of the affinity between Protein A expressed in S. aureus and Fc fragment of the antibody (Figure 1(a)). After being placed in an AMF (6.9 kA/ $\mathrm{m}, 80 \mathrm{kHz}$ ) for $60 \mathrm{~min}$, both free MO-1 cells and antibody(ab-) coated MO-1 cells induced a temperature rise to approximately $43^{\circ} \mathrm{C}$ (Figure $1(\mathrm{~b})$ ), and the length of the wound in mouse tail was reduced more significantly by ab-coated $\mathrm{MO}$ 1 (Figure 1(c)). It is suggested that the heat effect induced by MNPs under an AMF offers an alternative for treatment of diseases caused by resistant microbe.

2.1.3. Mechanisms. The temperature rise is probably the major reason for tumor or bacterial cell death when using 
high doses of MNPs for hyperthermia. Since heat shock proteins (HSP) are molecules that reflect any intracellular temperature change, some studies determined the expression of HSP-related genes. Yang et al. showed that the expression of HSP90 in magnetic hyperthermia-treated human liver cancer stem-like cells (LCSCs) was upregulated when temperature arose into $43^{\circ} \mathrm{C}$ caused by MNPs under an AMF $(200 \mathrm{kHz}$, $60 \mathrm{~min}$ ) [65]. The inhibition of HSP90 could sensitize LCSCs to magnetic hyperthermia and enhanced antitumor effects in vitro and in vivo. Court et al. also found that HSPA6 encoding the heat shock protein 70 was upregulated in ovarian cancer cells after the cells were incubated with carboxymethyl dextran coated iron oxide nanoparticles and then exposed to an $\operatorname{AMF}(36 \mathrm{kA} / \mathrm{m}, 245 \mathrm{kHz})$ for $30 \mathrm{~min}$ to induce a temperature rise to $43^{\circ} \mathrm{C}$ [66]. They also demonstrated that HSP70 inhibition synergistically enhanced the effects of magnetic fluid hyperthermia in ovarian cancer. Therefore, for common magnetic hyperthermia, high doses of MNPs (approximately $165 \mathrm{pg}$ Fe/cell [67]) cause temperature rise under an AMF which results in the cell death. Besides, the high heat stress possibly caused some cell emergency reactions, such as producing reactive oxygen species (ROS) which are harmful to tumor cells. We will talk about the free radical effect later.

\subsection{Lower Doses of MNPs in an Alternating Magnetic Field}

2.2.1. Cellular Effects without a Perceptible Macroscopic Temperature Rise. Compared to common magnetic hyperthermia, targeted magnetic hyperthermia allows MNPs to combine with or incorporate into tumor cells. As a result, the way permitted lower doses of MNPs around cells (about $2.2 \mathrm{pg}$ $\mathrm{Fe} / \mathrm{cell}$ [68]), where a perceptible macroscopic temperature rise is not monitored when exposed to an AMF. However, the direct cellular effect in a context of this sort is still confirmed to be effective. Creixell et al. reported that targeted magnetic nanoparticles under an AMF ( $37.5 \mathrm{kA} / \mathrm{m}, 233 \mathrm{kHz})$ for $60 \mathrm{~min}$ can induce cell death even at a constant temperature of 37 $\pm 0.2^{\circ} \mathrm{C}$ in a global solution [7]. Asín et al. obtained the controlled cell death of MNP-loaded DCs by adequate tuning of the physical AMF parameters and MNPs concentration while the temperature of the cell cultures remained essentially constant during AMF application [69]. Domenech et al. demonstrated that EGF-tagged MNPs were first internalized by MNA-MB-231 cancer cells and when exposed to an AMF $(41.75 \mathrm{kA} / \mathrm{m}, 233 \mathrm{kHz})$ for $60 \mathrm{~min}$ MNPs can result in tumor cell death in a constant temperature of $37^{\circ} \mathrm{C}$ [70]. Sanchez et al. used Gastrin whose receptors were overexpressed in several malignant cancers to decorate MNPs for treating INR1G9-CCK2R tumoral endocrine cells under an AMF $(51.6 \mathrm{kA} / \mathrm{m}, 275 \mathrm{kHz}, 120 \mathrm{~min})$ and finally found that cell apoptosis was caused without a temperature change [68]. Villanueva et al. also showed that particles could cause cellular damage which can lead to cell death under an AMF $(12 \mathrm{kA} / \mathrm{m}, 100 \mathrm{kHz}, 3 \mathrm{~min})$, although the temperature of the cell medium only increases by $0.5^{\circ} \mathrm{C}$ from $37^{\circ} \mathrm{C}$ [71]. After MNPs were incorporated into Crithidia fasciculate, Grazú et al. found that massive cell death was induced under an AMF $(13 \mathrm{kA} / \mathrm{m}, 249 \mathrm{kHz}, 30 \mathrm{~min})$ yet with no macroscopic rise in temperature [72]. Targeted magnetic hyperthermia could not hurt normal tissue around tumor and allows MNPs to reach deep tissue and so these studies supported a novel idea for related disease therapy.

2.2.2. Mechanisms. So what does the cellular effect attribute in the condition? As described above, overexpression of HSP was found due to temperature rise in common magnetic hyperthermia. However, regarding the case of no macroscopic temperature rise in MNPs mediated hyperthermia under an AMF, detection of the expression of HSP gene was not found. It needs further investigations to confirm the microscopic temperature changes. Fortunately, the local temperature around MNPs could be investigated and measured by using methods of biotechnology and nanotechnology. Riedinger et al. demonstrated that the temperature increased to $45^{\circ} \mathrm{C}$ within $0.5 \mathrm{~nm}$ of MNPs surface when exposed to an $\operatorname{AMF}(13.5 \mathrm{kA} / \mathrm{m}, 334.5 \mathrm{kHz})$ and decreased exponentially with increasing distance [73]. Dias et al. observed a high temperature $\left(8.3^{\circ} \mathrm{C}\right)$ at a distance of $5 \mathrm{~nm}$ from the nanoparticle $(12 \mathrm{~nm}$ in diameter) surface under a harsh AMF $(25 \mathrm{kA} / \mathrm{m}$, $835.25 \mathrm{kHz}$ ); moreover, the temperature rise decreased with distance [74]. From the point of view of these results, the local high temperature around MNPs may damage cell or organelle membrane, resulting in the release of cathepsins [70] from lysosomes in magnetic hyperthermia and then causing cell apoptosis or death. However, further studies must be conducted to elucidate the mechanism(s) leading to lysosome permeabilization and cell death.

2.2.3. Cell Regulation. Considering the local temperature rise around MNPs under an alternating magnetic field, on the other hand, some scholars tried to use local high temperature to induce cellular effects, such as regulation of cell behaviors. They first attached MNPs to a temperaturesensitive ion channel and then applied an AMF to generate a local temperature rise around MNPs. Subsequently, the temperature-sensitive ion channel could be activated by the high temperature. Huang et al. overexpressed a fusion protein of a transient receptor potential vanilloid-1 (TRPV1, a temperature-sensitive cation channel) and biotin in plasmic membrane and conjugated the fusion protein to streptavidincoated manganese ferrite $\left(\mathrm{MnFe}_{2} \mathrm{O}_{4}\right)$ nanoparticles; when placed in a radio-frequency magnetic field $(0.672 \mathrm{kA} / \mathrm{m}$, $40 \mathrm{MHz}$ ) for $30 \mathrm{~s}$, the channel was activated by heat [75]. Chen et al. targeted $\mathrm{Fe}_{3} \mathrm{O}_{4}$ nanoparticles to TRPV1 and found that the nanoparticles triggered widespread and reversible firing of TRPV1 ${ }^{+}$neurons when interacting with an AMF $(15 \mathrm{kA} / \mathrm{m}$, $500 \mathrm{kHz}$ ) [76]. Further, the interplay of iron oxide nanoparticles with an AMF was applied for deep brain stimulation [76] and regulation of plasma glucose in mice [77]. The paramagnetic protein ferritin was recently used as substitute for MNPs. Stanley et al. developed a genetically encoded system where GFP-tagged ferritin associated intracellularly with a camelid anti-GFP-TRPV1 fusion protein, which can activate ion channel by the interaction of ferritin with noninvasive radio waves $(25.6 \mathrm{kA} / \mathrm{m}, 465 \mathrm{kHz})$ [78]. They also demonstrated that the system could be used to lower blood glucose by remotely stimulating insulin transgene expression with a radio-frequency magnetic field [78]. Later the same group 
improved the genetically encoded system for noninvasive, temporal activation or inhibition of neuronal activity in vivo by radio-frequency treatment and described its use to study central nervous system control of glucose homeostasis and feeding in mice [79]. These studies offer us new tools to regulate cell functions.

However, the controversy over the temperature gradient around MNPs under an AMF existed as well. Some theoretical and experimental analyses showed that the temperature rise on the surface of MNPs was negligible [80-82]. Moreover, Meister calculated the thermal energy induced by ferritin under radio-frequency magnetic field and found that either temperature increase or gradient cannot activate TRPV1 [83]. There might also be other mechanisms in the process.

\section{Effect of Mechanical Force}

Due to magnetic properties, MNPs are able to create mechanical force or torque when interacting with magnetic fields. If MNPs conjugate to the cell membrane or are incorporated into cells, mechanical force could directly give rise to cellular effects.

3.1. Under High Frequency Magnetic Fields. Generally, magnetic hyperthermia employs MNPs with the property of superparamagnetism and isotropy. Upon applying an alternating magnetic field, MNPs will display the phenomenon of translational or rotating motions by Brown relaxation which generates shear forces [84]. The kind of mechanical force may make cells broken directly or cause the incompleteness of organelles that then induced cell apoptosis. Carrey et al. theoretically studied and showed that MNPs oscillate mechanically in an inhomogeneous AMF with the great possibility of creating shear force [85]. The theoretical results also showed that oscillating MNPs may generate ultrasound. Ultrasound is proved to give rise to cell apoptosis or dissolution [86, 87]. Cheng et al. used rod-shaped MNPs to induce HeLa cell viability decrease by about 2 -fold than spherical MNPs with the temperature rise of $1.7^{\circ} \mathrm{C}$ after being exposed to an AMF (35 kHz), suggesting that AMF-induced oscillation of MNPs was able to mechanically damage cancer cells in vitro [40]. However, Hallali et al. took advantage of a static magnetic field $(55 \mathrm{mT})$ which prevents heating of MNPs and maximized MNPs motion when superimposed to an alternating magnetic field gradient $(1.4 \mathrm{~T} / \mathrm{m}, 393 \mathrm{kHz})$ and found no decrease in cell viability, suggesting that translational motions could not be involved in cell death during magnetic hyperthermia experiments [88]. The parameters used in certain studies were shown in Table 2.

3.2. Under Constant or Low Frequency Magnetic Field. MNPs are also placed in magnetic fields with low frequency to create mechanical force which directly induces cellular effects. Zhang et al. demonstrated that isotropous $\mathrm{Fe}_{3} \mathrm{O}_{4}$ nanoparticles could be rotationally activated in a unique dynamic magnetic field $(20 \mathrm{~Hz})$ and after MNPs were internalized into cells and bound to lysosomes, the rotationally activated MNPs generated shear forces which resulted in rapid decrease in size and number of lysosomes, attributable to tearing of the lysosomal membrane [41]. With regard to the effect induced by rotating MNPs under the magnetic field, Yue et al. theoretically investigated the interaction mechanism between lipid membranes and rotating MNPs through simulation and found that the rotating nanoparticles promoted cell uptake and also induced the mechanical membrane rupture [89]. The theoretical analysis has the potential to provide both qualitative and quantitative guidelines for the application of MNPs under an external magnetic field in a variety of biomedical areas while minimizing the cytotoxicity. Anisotropic MNPs are supposed to be overturning or swinging in a especial magnetic field with low frequency. Kim et al. first found that iron-nickel microdiscs that possess a spin-vortex ground state shift under an alternating magnetic field $(<60 \mathrm{~Hz})$; the oscillation of microdiscs compromised integrity of the cellular membrane when interfacing with cells and then initiated programmed cell death [42]. They also speculated that the mechanical oscillation of microdiscs attached to the cancercell membrane may be transformed into an ionic electrical signal, which triggers the programmed cell-death pathway. Cheng et al. demonstrated that a low frequency $(20 \mathrm{~Hz})$, rotating magnetic field could induce the rotating of spinvortex, disk-shaped permalloy magnetic particles, creating enough mechanical force that can destruct cell membrane of glioma cells [43]. A swing magnetic field with low frequency and low heat-production was designed by Chen et al. in order to evaluate the torque effect of magnetotactic bacteria on S. aureus (Figures 2(a) and 2(b)) [44]. Under the swing magnetic field $(10 \mathrm{mT}, 2 \mathrm{~Hz})$, the addition of magnetotactic bacteria in suspension of $S$. aureus caused negligible temperature increase (Figure 2(c)), and S. aureus was killed only when attached to magnetotactic bacteria (Figure 2(d)) [44]. Finally, we analyzed and calculated the mechanical force created by magnetotactic bacteria under the swing magnetic field with a value of $8.3 \mathrm{kPa}$. According to previous reports $[90,91]$, the mechanical force may be enough to induce the damage of $S$. aureus or directly kill the pathogen. Compared with MNPs that used to generate heat, MNPs are capable of doing the motions of oscillation and rotation when exposed to magnetic fields of low frequency, suitable for producing mechanical forces. The manner of producing forces avoids the heat dissipation to the normal tissue near nanoparticles when treating tumor. And magnetic fields of low frequencies can safely be used therapeutically to penetrate the human body, including the head, without damaging the biological tissues. Some parameters used in these references are shown in Table 2.

Actually, the mechanical force from the interaction of MNPs and magnetic fields has been used for controlling cell status (Figure 3). The different kind of magnetic field may produce different forces via MNPs. By applying a magnetic field gradient, MNPs get a drag force (Figure 3(a)). When the nanoparticles bind to ion channels, the drag force may switch on ion channels. Hughes et al. showed that manipulation of $\mathrm{Fe}_{3} \mathrm{O}_{4}$ MNPs that targeted against a mechanosensitive ion channel TREK-1 by a gradient magnetic field $(80 \mathrm{mT}, 5.5 \mathrm{~T} / \mathrm{m})$ could lead to the change of TREK-1 activity and the whole-cell currents [45]. Lee et al. proved that cube-shaped $\mathrm{Zn}-\mathrm{Fe}_{3} \mathrm{O}_{4}$ MNPs bound to glycoprotein of cellular membranes and that 
TABLE 2: Different MNPs under magnetic fields in the effect of mechanical force.

\begin{tabular}{|c|c|c|c|c|c|c|c|c|}
\hline \multirow{2}{*}{ Role } & \multirow{2}{*}{ Kind of MNPs } & \multirow{2}{*}{$\begin{array}{c}\text { Average } \\
\text { size of MNPs }\end{array}$} & \multirow{2}{*}{ Ration } & \multirow{2}{*}{ Cell } & \multicolumn{2}{|c|}{ Magnetic field } & \multirow{2}{*}{$\begin{array}{l}\text { Exposure } \\
\text { time }\end{array}$} & \multirow{2}{*}{ Ref } \\
\hline & & & & & Intensity & Frequency & & \\
\hline \multirow{5}{*}{$\begin{array}{l}\text { Mechanical } \\
\text { force to destruct } \\
\text { cells }\end{array}$} & Rod- $\mathrm{Fe}_{3} \mathrm{O}_{4}$ & $\begin{array}{c}200 \mathrm{~nm} \text { length } \\
50-200 \mathrm{~nm} \\
\text { diameter }\end{array}$ & $100 \mu \mathrm{g} / \mathrm{ml}$ & Hela cell & - & $\begin{array}{c}35 \mathrm{kHz} \\
\text { (high) }\end{array}$ & $2 \mathrm{~h}$ & {$[40]$} \\
\hline & $\mathrm{Fe}_{3} \mathrm{O}_{4}$ & $100 \mathrm{~nm}$ & $10 \mathrm{mg} / \mathrm{ml}$ & Rat INS-1 & $30 \mathrm{mT}$ & $20 \mathrm{~Hz}$ (low) & $20 \mathrm{~min}$ & {$[41]$} \\
\hline & $\begin{array}{l}\text { Iron/nickel } \\
\text { microdiscs }\end{array}$ & $\begin{array}{c}1 \mu \mathrm{m} \text { diameter } \\
70 \mathrm{~nm} \\
\text { thickness }\end{array}$ & $\begin{array}{c}10 \\
\text { microdiscs/cell }\end{array}$ & $\begin{array}{l}\text { N10 glioma } \\
\text { cells }\end{array}$ & $9 \mathrm{mT}$ & $\begin{array}{c}<60 \mathrm{~Hz} \\
\text { (low) }\end{array}$ & $10 \mathrm{~min}$ & {$[42]$} \\
\hline & $\begin{array}{l}\text { Iron/nickel } \\
\text { microdiscs }\end{array}$ & $\begin{array}{c}2 \mu \mathrm{m} \text { diameter } \\
70 \mathrm{~nm} \\
\text { thickness }\end{array}$ & $\begin{array}{c}50 \\
\text { microdiscs/cell }\end{array}$ & U87 cell & $1 \mathrm{~T}$ & $20 \mathrm{~Hz}$ (low) & $30 \mathrm{~min}$ & {$[43]$} \\
\hline & MO-1 & $1.5 \mu \mathrm{m}$ & $\begin{array}{c}10(\mathrm{MO}-1): 1 \\
(\mathrm{SA})\end{array}$ & $\begin{array}{l}\text { S. aureus } \\
(\mathrm{SA})\end{array}$ & $10 \mathrm{mT}$ & $2 \mathrm{~Hz}$ (low) & $1 \mathrm{~h}$ & {$[44]$} \\
\hline \multirow{3}{*}{$\begin{array}{l}\text { Drag force for } \\
\text { regulation }\end{array}$} & $\mathrm{Fe}_{3} \mathrm{O}_{4}$ & $250 \mathrm{~nm}$ & $50-200 \mu \mathrm{g} / \mathrm{ml}$ & COS-7 & $8 \mathrm{mT}(5.5 \mathrm{~T} / \mathrm{m})$ & $1 \mathrm{~Hz}$ (low) & - & {$[45]$} \\
\hline & $\mathrm{Zn}_{0.4} \mathrm{Fe}_{2.6} \mathrm{O}_{4} @ \mathrm{SiO}_{2}$ & $50 \mathrm{~nm}$ & $0.1 \mathrm{mg} / \mathrm{ml}$ & $\begin{array}{l}\text { Inner ear hair } \\
\text { cells }\end{array}$ & $\begin{array}{c}10 \mathrm{mT} \\
1000 \mathrm{~T} / \mathrm{m}\end{array}$ & $\begin{array}{c}<10 \mathrm{kHz} \\
\text { (high) }\end{array}$ & - & [46] \\
\hline & fMNPs & $100 \mathrm{~nm}$ & $1.25 \mathrm{~g} / \mathrm{cm}^{3}$ & $\begin{array}{l}\text { Cortical } \\
\text { neurons }\end{array}$ & $110 \mathrm{mT}$ & - & - & {$[47]$} \\
\hline \multirow{2}{*}{$\begin{array}{l}\text { Magnetic torque } \\
\text { for regulation }\end{array}$} & $\begin{array}{c}\text { Ferromagnetic } \\
\text { microbead }\end{array}$ & - & - & $\begin{array}{l}\text { Endothelial } \\
\text { cell }\end{array}$ & $0-25 \mathrm{Gs}$ & - & - & {$[48]$} \\
\hline & $\begin{array}{c}\text { Ferromagnetic } \\
\text { bead }\end{array}$ & $4 \mu \mathrm{m}$ & - & Mouse ESC & $25 \mathrm{Gs}$ & $0.3 \mathrm{~Hz}$ (low) & $1 \mathrm{~h}$ & [49] \\
\hline \multirow{4}{*}{$\begin{array}{l}\text { Aggregation of } \\
\text { cell regulation }\end{array}$} & $\mathrm{Zn}_{0.4} \mathrm{Fe}_{2.6} \mathrm{O}_{4}$ & $15 \mathrm{~nm}$ & $1 \mathrm{pM}$ & $\begin{array}{l}\text { DLD-1 colon } \\
\text { cancer cell }\end{array}$ & $0.2 \mathrm{~T}$ & I & $4 \mathrm{~h}$ & {$[50]$} \\
\hline & Zn-MNPs & $15 \mathrm{~nm}$ & $4 \mu \mathrm{g}$ & 293-hTie2 cell & $0.15 \mathrm{~T}$ & I & $1 \mathrm{~h}$ & {$[51]$} \\
\hline & $\begin{array}{l}\text { Iron-dextran } \\
\text { nanoparticle }\end{array}$ & $50-100 \mathrm{~nm}$ & - & $\mathrm{T}$ cell & $0.2 \mathrm{~T}$ & I & $30 \mathrm{~min}$ & {$[52]$} \\
\hline & Microbead & $30 \mathrm{~nm}$ & - & Mast cells & $0.1 \mathrm{~T}$ & I & $\sim$ & {$[53]$} \\
\hline
\end{tabular}

their interplay with a magnetic field $(10 \mathrm{mT}, 1000 \mathrm{~T} / \mathrm{m})$ from an electromagnet can exert mechanical force on the cells, inducing the influx of ions into the hair cell [46]. Tay et al. used ferromagnetic nanoparticles under a gradient magnetic field to trigger calcium influx in cortical neural networks [47]. Different from the drag force, the torque of MNPs from the change of direction of an applied magnetic field was also used to control cells (Figure 3(b)). Under the circumstances, MNPs may twist or swing and induce the change of protein conformation, opening MNPs-binding ion channels. Here an important thing to note is that when superparamagnetic nanoparticles are used, a magnetized field should be first applied to magnetize the kind of MNPs. After applying a strong external magnetic field to magnetize the modified microbeads, Wang et al. used the magnetized microbeads under a $90^{\circ}$-oriented magnetic field to create a torque that could induce the deformation of cell cytoskeleton [48]. Chowdhury et al. also used a strong magnetic impulse to magnetize the microbeads that attached to mouse embryonic stem cells and found that microbeads promoted early development of stem cells via applying a twisting field [49]. Besides, when applying a magnetic field, MNPs aggregate due to their magnetism. As MNPs were modified with ligands or antibody and can bind to related receptors, the aggregation of MNPs may induce the cluster of receptors and then initiate signal transduction, which is another approach to regulate cells (Figure 3(c)). Cho et al. applied a static magnetic field $(0.2 \mathrm{~T})$ to aggregate MNPs bound death receptor 4 , which then promotes apoptosis signaling pathways [50]. Perica et al. modified MNPs by $\mathrm{T}$ cell activating proteins to be artificial antigen presenting cells; when applying a magnetic field $(0.15 \mathrm{~T})$ the aggregation of MNPs resulted in the activation and expansion of T cells [51]. As shown in Table 2, we have also summarized other studies where mechanical force was used to regulate cells.

Recently, the iron-sulfur cluster assembly protein 1 or ferritin has been used to regulate cells by interplaying with magnetic fields. Different from the attachment of MNPs to ion channels via chemical methods, iron-sulfur cluster assembly protein 1 or ferritin is coexpressed with ion channels through genetic tools to form a fusion protein. Then an external magnetic field is applied to induce cellular effect. Long et al. expressed an iron-sulfur cluster assembly protein 1 in HEK-293 cells and cultured hippocampal neurons and showed that application of the external magnetic field resulted in membrane depolarization and calcium influx [92]. Wheeler et al. fused the cation channel TRPV4 to ferritin to form a single-component, magnetically sensitive actuator, "Magneto," and validated noninvasive magnetic control over neuronal activity using the "Magneto" [93]. The method of 


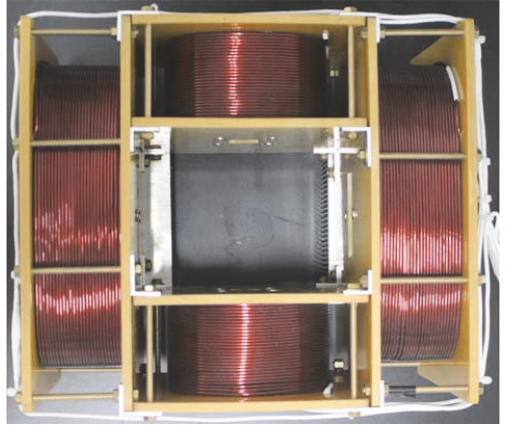

(a)

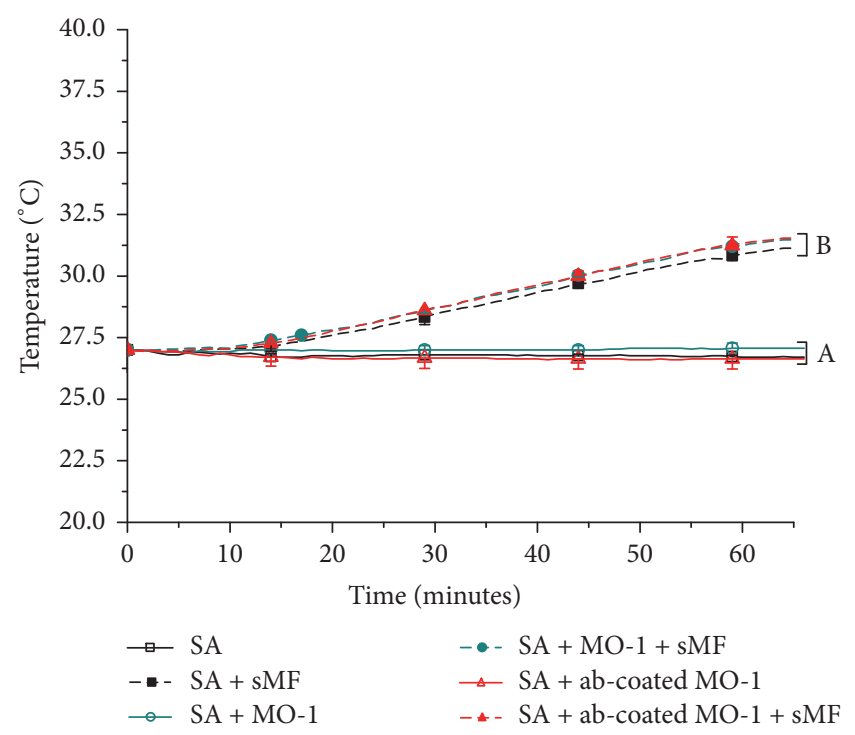

(c)

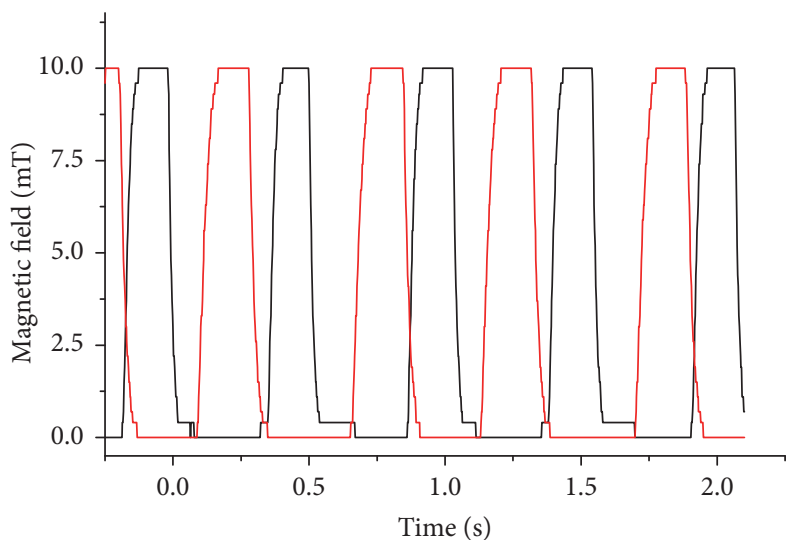

— Magnetic field produced by coils A

_ Magnetic field produced by coils B

(b)

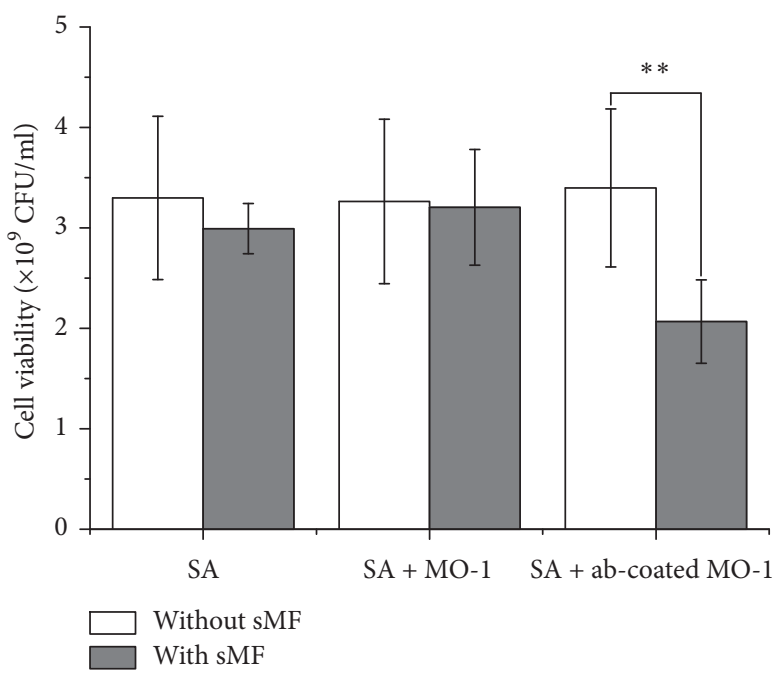

(d)

FIgURE 2: Killing of $S$. aureus by magnetotactic bacteria in a swing magnetic field. (a) The coils of the swing magnetic field generator. (b) The swing magnetic field with the intensity of $10 \mathrm{mT}$ and the frequency of $2 \mathrm{~Hz}$. (c) The temperature measured in $S$. aureus alone suspensions, the mixed suspension of $S$. aureus with free MO-1 cells, and the attached suspension of antibody-coated MO-1 cells to $S$. aureus with or without the swing magnetic field. (d) The killing effect of magnetotactic bacteria under the swing magnetic field on S. aureus. Panels (b), (c), and (d) are reproduced with permission from [44]. Copyright (c) 2017 Copyright Clearance Center, Inc. In Figure $2(\mathrm{~d}), * *$ refers to $P<0.01$.

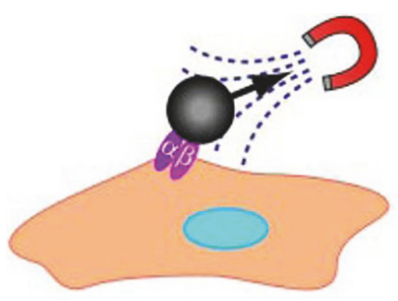

(a) Drag force

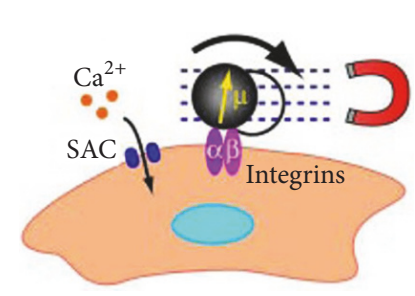

(b) Magnetic torque

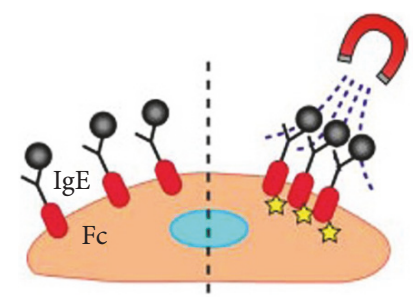

(c) Aggregation

FIGURE 3: Mechanical force from the interaction of MNPs and magnetic fields for controlling cell status. (a) By applying a gradient magnetic field, the magnetic nanoparticles get a drag force used for the control of cells. (b) The mechanical torque induced by MNPs from the change of direction of the applied magnetic field was also used to control cells. (c) Aggregation of MNPs may induce the cluster of MNPs-attached receptors under a magnetic field and then initiate the signal transduction. Copyright $\odot$ 2010, Endocrine Society. 
using the iron-sulfur cluster assembly protein 1 or ferritin provides a more compatible strategy than using the extraneous MNPs in cell regulation, especially in applications of nervous system. However, the in vivo expression of fusion proteins is also challenging.

MNPs with different properties can generate mechanical force or torque under different kinds of magnetic fields. On the one hand, the mechanical force or torque could induce cellular effects by directly destructing cell membrane or lysosomal membrane. On the other hand, the mechanical force or torque changes the condition of the cytoskeleton, intracellular ion channel, mitochondria, or other signal transduction pathway. It follows that cells may experience different status, such as growth, differentiation, or death. Particularly, the abnormal conditions of ion channel trigged by mechanical force, that is, the abnormal switch on-off and excessive open or close, can induce cell apoptosis and death (see reviews [94-96]). It provides us with a new thought for cell regulation or diseases therapy. However, the theoretical calculation from Meister showed that mechanical force via the interaction of ferritin with different kinds of magnetic fields was unable to gate the ion channels [83]. Insufficient consideration of factors in live cells may be a reason that leads to the contradiction. Moreover, besides the heat and mechanical force, the interaction of MNPs with magnetic fields may result in chemical reactions such as free radical reaction. The kind of the undetermined mechanism may also be an important reason.

\section{Effect of Free Radical}

Free radicals such as reactive oxygen species (ROS) are the product of cellular metabolism and participate in physiological functions. However, external environment of MNPs alone or combined with magnetic field could influence ROS production in cells.

On the one hand, several studies have already shown that the use of MNP alone causes adverse effects on biological cells. Dwivedi et al. showed that $\mathrm{Fe}_{3} \mathrm{O}_{4}$-nanoparticles induced cell viability decrease in a dose-dependent manner $(10-50 \mu \mathrm{g} /$ $\mathrm{ml}$ ) and are likely to be mediated through the oxidative stress and ROS generation in A549 cells [97]. Wang et al. showed that the internalized MNPs inhibited the viability of neuro$2 \mathrm{a}$ cells in a dose-dependent manner $(100-500 \mu \mathrm{g} / \mathrm{ml})$ and triggered the endoplasmic reticulum stress response along with induced ROS production [98]. Naqvi et al. exposed murine macrophage (J774) cells to Tween 80 coated MNPs solution and found that high concentration of Tween 80 coated MNPs resulted in enhanced ROS generation, leading to more cell injury and death [99]. Therefore, the generation of ROS has been described to be one of the main causes of adverse effects of MNPs. It is reported, however, that MNPs could also act as ROS scavenger. Gao et al. and Chen et al. reported that $\mathrm{Fe}_{3} \mathrm{O}_{4}$ nanoparticles were actually found to have the catalytic activity of peroxidase and catalase, which is supposed to be a scavenger that eliminates ROS in the cells $[100,101]$. Huang et al. described the ability of superparamagnetic iron oxide nanoparticles as a scavenger to diminish intracellular $\mathrm{H}_{2} \mathrm{O}_{2}$ through intrinsic peroxidaselike activity, which further promotes cell growth [102]. In fact, the characteristic of ROS scavenger of MNPs is also related to their surface coating. Yu et al. showed that dextran and polymer polyethylene glycol (PEG) coated MNPs ( $30 \mathrm{~nm}$ in diameter, $0.5 \mathrm{mg} / \mathrm{mL}$ ) reduced the generation of ROS and then improved cell viability of porcine aortic endothelial cells, relatively to the bare MNPs [103].

On the other hand, magnetic fields interplay with MNPs, also affecting the generation of ROS. Domenech et al. demonstrated that lysosomal membrane permeabilization induced by MNPs under an AMF is correlated with the production of ROS [70]. Further, Connord et al. recorded AMF-induced production of ROS in cells having incorporated DY647MNPs-gastrin in a real-time form and found that ROS level within cells submitted to the AMF $(42.4 \mathrm{kA} / \mathrm{m}, 300 \mathrm{kHz})$ increased significantly compared to the cells outside the AMF [104]. Upon application of a static magnetic field (0.4 T) for $1 \mathrm{~h}$, Bae et al. described that MNPs exerted synergistic adverse effects such as reduced cell viability, apoptosis, and cell cycle aberrations on hepatocytes in vitro and in vivo and that the apoptotic effect was dependent on levels of ROS [105]. Jia et al. incubated differentiated rat pheochromocytoma cells with MNPs- $\mathrm{SiO}_{2}$ and then exposed them to extremely low frequency magnetic field $(50 \mathrm{~Hz}, 400 \mu \mathrm{T})$, resulting in remarkable cytotoxicity and increased cell apoptosis [106]. Superabundant free radicals attack almost all of macromolecules including DNA, protein, carbohydrate, and lipids and hence are harmful to cells. On the contrary, others reported that MNPs may also decrease intracellular free radicals under magnetic fields. A study by $\mathrm{Pal}$ et al. showed that MNPs could significantly decrease $\mathrm{H}_{2} \mathrm{O}_{2}$-mediated oxidative stress in combination with an external electromagnetic field $(50 \mathrm{~Hz}, 17.96 \mu \mathrm{T})$ and act as free radical scavenger in the cure of spinal cord injury [107]. Shin et al. also demonstrated that magnetosomes enhanced cell growth and have antiapoptotic effect in a static magnetic field ( $480 \mathrm{mT})$ [108]. However, they attributed the positive effect to the factor that the interplay of magnetosomes with external static magnetic field within the cell may induce the alteration of the diamagnetic anisotropy of membrane phospholipids, resulting in modulation of cell signaling related to the membrane protein and the enhanced cell growth.

Thus, based on currently available data, it seems likely that MNPs could influence the different cellular effect by free radicals. On the one hand, magnetic nanoparticles could play a role in catalytic ROS production. Through the release of $\mathrm{Fe}^{2+}$, MNPs take part in the production of ROS by Fenton reaction. It is dramatically noted that exposure to a magnetic field may promote the process. Wydra et al. described the accelerated generation of free radicals by $\mathrm{Fe}_{3} \mathrm{O}_{4} \mathrm{MNPs}$ in the presence of an AMF (60 kA/m,292 kHz) [109]. Binhi also theoretically analyzed the generation of free radicals by MNPs in a static magnetic field $(0.4 \mu \mathrm{T})$ and found that MNPs can increase the rate of free radical formation [110]. Besides, magnetic field generated by MNPs around themselves is orders of magnitude greater than the applied magnetic field $[106,111]$. 
The high magnetic field around MNPs may impact radical pair spin states, resulting in the decrease of recombination rates of radical pair particles [112]. As a result, free radical generation increases. Of course, Zhao et al. and Yoshikawa et al. described that the heat stress created by MNPs under an AMF is likely to induce the production of free radicals $[113,114]$. On the other hand, MNPs alone or under magnetic fields show the activity of scavenger that can protect and even enhance cell growth. Overall, the different direct cellular effect of free radicals possibly offers new clues for study of cell metabolism and disease treatment. Yet cellular effects of free radicals induced by MNPs under magnetic fields and their underlying mechanism should be studied deeply.

\section{Conclusion and Future Perspectives}

In this account, we reviewed concisely direct cellular effects of magnetic nanoparticles under different kinds of magnetic fields. We introduced the first cellular effect of magnetic nanoparticles under an alternating magnetic field which could be used in tumor therapy and infection treatment. The mechanism of cellular effect depends on the heat or temperature gradient around MNPs. Then cellular effect of mechanical force was discussed particularly in cell regulation as the interaction of MNPs with a magnetic field could create mechanical forces. The mechanical force could influence ion channels or damage the cell membrane and further change the cell status containing cell apoptosis or death. Meanwhile, it is found that mechanical force might be involved in the cellular effect caused by heat. Finally, direct cellular effect of free radicals generated by MNPs was analyzed. It is interesting that MNPs alone or under magnetic fields show their doublefaced behaviors of promoting ROS production and as a ROS scavenger. Although some current understanding of cellular effects directly induced by MNPs in magnetic fields was shown here, some questions about how MNPs could directly induce cellular effect are still indistinct. The mechanisms of the cellular effect of heat and the relationship of MNPs' peroxidase-like activity with magnetic fields need to be confirmed. Therefore, more studies and experimental exploration into these mechanisms are quietly required and can further lead to significant advances in various areas of in-depth biomedical applications of MNPs under magnetic fields such as precision medicine of diseases, cell, or nerve regulation.

\section{Conflicts of Interest}

The authors declare that there are no conflicts of interest regarding the publication of this paper.

\section{Authors' Contributions}

Linjie Chen and Changyou Chen contributed equally to this work.

\section{Acknowledgments}

This work was supported by the National Natural Science Foundation of China (NSFC) (31300689).

\section{References}

[1] A. Sobczak-Kupiec, J. Venkatesan, A. Alhathal AlAnezi et al., "Magnetic nanomaterials and sensors for biological detection," Nanomedicine: Nanotechnology, Biology and Medicine, vol. 12, no. 8, pp. 2459-2473, 2016.

[2] S. Behrens and I. Appel, "Magnetic nanocomposites," Current Opinion in Biotechnology, vol. 39, pp. 89-96, 2016.

[3] X. Sun and S. Sun, "Preparation of magnetic nanoparticles for biomedical applications," in Biomedical Nanotechnology, vol. 1570 of Methods in Molecular Biology, pp. 73-89, Springer New York, New York, NY, 2017.

[4] K. Strojan, J. Lojk, V. B. Bregar, P. Veranič, and M. Pavlin, "Glutathione reduces cytotoxicity of polyethyleneimine coated magnetic nanoparticles in CHO cells," Toxicology in Vitro, vol. 41, pp. 12-20, 2017.

[5] S. Rana, N. G. Shetake, K. C. Barick, B. N. Pandey, H. G. Salunke, and P. A. Hassan, "Folic acid conjugated Fe," Dalton Trans., vol. 45, no. 43, pp. 17401-17408, 2016.

[6] K. H. Bae, M. Park, M. J. Do et al., "Chitosan oligosaccharidestabilized ferrimagnetic iron oxide nanocubes for magnetically modulated cancer hyperthermia," ACS Nano, vol. 6, no. 6, pp. 5266-5273, 2012.

[7] M. Creixell, A. C. Bohórquez, M. Torres-Lugo, and C. Rinaldi, "EGFR-targeted magnetic nanoparticle heaters kill cancer cells without a perceptible temperature rise," ACS Nano, vol. 5, no. 9, pp. 7124-7129, 2011.

[8] Z. Wang, R. Qiao, N. Tang et al., "Active targeting theranostic iron oxide nanoparticles for MRI and magnetic resonanceguided focused ultrasound ablation of lung cancer," Biomaterials, vol. 127, pp. 25-35, 2017.

[9] H. Chen, L. Wang, Q. Yu et al., "Anti-HER2 antibody and ScFvEGFR-conjugated antifouling magnetic iron oxide nanoparticles for targeting and magnetic resonance imaging of breast cancer," International Journal of Nanomedicine, vol. 8, pp. 37813794, 2013.

[10] R. P. Blakemore, "Magnetotactic bacteria," Annual Review of Microbiology, vol. 36, pp. 217-238, 1982.

[11] D. A. Bazylinski and R. B. Frankel, "Magnetosome formation in prokaryotes," Nature Reviews Microbiology, vol. 2, no. 3, pp. 217-230, 2004.

[12] R. B. Frankel and D. A. Bazylinski, "Magnetosomes and magneto-aerotaxis," Contributions to Microbiology, vol. 16, pp. 182193, 2009.

[13] R. Qiao, C. Yang, and M. Gao, "Erratum: superparamagnetic iron oxide nanoparticles: from preparations to in vivo MRI applications," Journal of Materials Chemistry, vol. 19, no. 48, p. 9286, 2009.

[14] T. Kubik, K. Bogunia-Kubik, and M. Sugisaka, "Nanotechnology on duty in medical applications," Current Pharmaceutical Biotechnology, vol. 6, no. 1, pp. 17-33, 2005.

[15] Wahajuddin and S. Arora, "Superparamagnetic iron oxide nanoparticles: magnetic nanoplatforms as drug carriers," International Journal of Nanomedicine, vol. 7, pp. 3445-3471, 2012.

[16] Y. W. Chu, D. A. Engebretson, and J. R. Carey, "Bioconjugated magnetic nanoparticles for the detection of bacteria," Journal of Biomedical Nanotechnology, vol. 9, no. 12, pp. 1951-1961, 2013. 
[17] R. Ivkov, "Magnetic nanoparticle hyperthermia: a new frontier in biology and medicine?" International Journal of Hyperthermia, vol. 29, no. 8, pp. 703-705, 2013.

[18] A. Singh and S. K. Sahoo, "Magnetic nanoparticles: a novel platform for cancer theranostics," Drug Discovery Today, vol. 19, no. 4, pp. 474-481, 2014.

[19] R. Hergt, S. Dutz, R. Müller, and M. Zeisberger, "Magnetic particle hyperthermia: nanoparticle magnetism and materials development for cancer therapy," Journal of Physics Condensed Matter, vol. 18, no. 38, pp. S2919-S2934, 2006.

[20] N. J. Sniadecki, "A tiny touch: activation of cell signaling pathways with magnetic nanoparticles," Endocrinology, vol. 151, no. 2, pp. 451-457, 2010.

[21] D. Kilinc, C. L. Dennis, and G. U. Lee, "Bio-nano-magnetic materials for localized mechanochemical stimulation of cell growth and death," Advanced Materials, vol. 28, no. 27, pp. 56725680, 2016.

[22] G. Vallejo-Fernandez, O. Whear, A. G. Roca et al., "Mechanisms of hyperthermia in magnetic nanoparticles," Journal of Physics D: Applied Physics, vol. 46, no. 31, Article ID 312001, 2013.

[23] A. E. Deatsch and B. A. Evans, "Heating efficiency in magnetic nanoparticle hyperthermia," Journal of Magnetism and Magnetic Materials, vol. 354, pp. 163-172, 2014.

[24] Q. A. Pankhurst, J. Connolly, S. K. Jones, and J. Dobson, “Applications of magnetic nanoparticles in biomedicine," Journal of Physics D: Applied Physics, vol. 36, no. 13, pp. R167-R181, 2003.

[25] M. Latorre and C. Rinaldi, "Applications of magnetic nanoparticles in medicine: magnetic fluid hyperthermia," Puerto Rico Health Sciences Journal, vol. 28, no. 3, pp. 227-238, 2009.

[26] A. Jordan, "Hyperthermia classic commentary: 'inductive heating of ferrimagnetic particles and magnetic fluids: physical evaluation of their potential for hyperthermia' by Andreas Jordan et al., International Journal of Hyperthermia, 1993;9:51-68," International Journal of Hyperthermia, vol. 25, no. 7, pp. 512-516, 2009.

[27] S. Dutz and R. Hergt, "Magnetic particle hyperthermia-a promising tumour therapy?" Nanotechnology, vol. 25, no. 45, Article ID 452001, 2014.

[28] F. K. Storm, H. W. Baker, E. F. Scanlon et al., "Magneticinduction hyperthermia. Results of a 5-year multi-institutional national cooperative trial in advanced cancer patients," Cancer, vol. 55, no. 11, pp. 2677-2687, 1985.

[29] R. T. Pettigrew, C. M. Ludgate, and A. N. Smith, "Proceedings: The effect of whole body hyperthermia in advanced cancer," British Journal of Cancer, vol. 30, no. 2, p. 179, 1974.

[30] T. Sadhukha, L. Niu, T. S. Wiedmann, and J. Panyam, "Effective elimination of cancer stem cells by magnetic hyperthermia," Molecular Pharmaceutics, vol. 10, no. 4, pp. 1432-1441, 2013.

[31] S. Balivada, R. S. Rachakatla, H. Wang et al., "A/C magnetic hyperthermia of melanoma mediated by iron(0)/iron oxide core/shell magnetic nanoparticles: a mouse study," BMC Cancer, vol. 10, article 119, 2010.

[32] S. Ota, N. Yamazaki, A. Tomitaka, T. Yamada, and Y. Takemura, "Hyperthermia using antibody-conjugated magnetic nanoparticles and its enhanced effect with cryptotanshinone," Nanomaterials, vol. 4, no. 2, pp. 319-330, 2014.

[33] T. Kikumori, T. Kobayashi, M. Sawaki, and T. Imai, "Anti-cancer effect of hyperthermia on breast cancer by magnetite nanoparticle-loaded anti-HER2 immunoliposomes," Breast Cancer Research and Treatment, vol. 113, no. 3, pp. 435-441, 2009.
[34] A. Chalkidou, K. Simeonidis, M. Angelakeris et al., "In vitro application of $\mathrm{Fe} / \mathrm{MgO}$ nanoparticles as magnetically mediated hyperthermia agents for cancer treatment," Journal of Magnetism and Magnetic Materials, vol. 323, no. 6, pp. 775-780, 2011.

[35] H. L. Rodríguez-Luccioni, M. Latorre-Esteves, J. Méndez-Vega et al., "Enhanced reduction in cell viability by hyperthermia induced by magnetic nanoparticles," International Journal of Nanomedicine, vol. 6, pp. 373-380, 2011.

[36] R. Ghosh, L. Pradhan, Y. P. Devi et al., "Induction heating studies of Fe3O4 magnetic nanoparticles capped with oleic acid and polyethylene glycol for hyperthermia," Journal of Materials Chemistry, vol. 21, no. 35, pp. 13388-13398, 2011.

[37] G. Wang, D. Xu, Q. Chai et al., "Magnetic fluid hyperthermia inhibits the growth of breast carcinoma and downregulates vascular endothelial growth factor expression," Oncology Letters, vol. 7, no. 5, pp. 1370-1374, 2014.

[38] Y. Du, D. Zhang, H. Liu, and R. Lai, “Thermochemotherapy effect of nanosized As2O3/Fe3O4 complex on experimental mouse tumors and its influence on the expression of CD44v6, VEGF-C and MMP-9," BMC Biotechnology, vol. 9, article no. 1472 , p. 84, 2009.

[39] J.-H. Lee, J.-T. Jang, J.-S. Choi et al., "Exchange-coupled magnetic nanoparticles for efficient heat induction," Nature Nanotechnology, vol. 6, no. 7, pp. 418-422, 2011.

[40] D. Cheng, X. Li, G. Zhang, and H. Shi, "Morphological effect of oscillating magnetic nanoparticles in killing tumor cells," Nanoscale Research Letters, vol. 9, no. 1, pp. 1-8, 2014.

[41] E. Zhang, M. F. Kircher, M. Koch, L. Eliasson, S. N. Goldberg, and E. Renström, "Dynamic magnetic fields remote-control apoptosis via nanoparticle rotation," ACS Nano, vol. 8, no. 4, pp. 3192-3201, 2014.

[42] D.-H. Kim, E. A. Rozhkova, I. V. Ulasov et al., "Biofunctionalized magnetic-vortex microdiscs for targeted cancer-cell destruction," Nature Materials, vol. 9, no. 2, pp. 165-171, 2010.

[43] Y. Cheng, M. E. Muroski, D. C. M. C. Petit et al., "Rotating magnetic field induced oscillation of magnetic particles for in vivo mechanical destruction of malignant glioma," Journal of Controlled Release, vol. 223, pp. 75-84, 2016.

[44] C. Chen, L. Chen, P. Wang, L. Wu, and T. Song, "Magneticallyinduced elimination of Staphylococcus aureus by magnetotactic bacteria under a swing magnetic field," Nanomedicine: Nanotechnology, Biology and Medicine, vol. 13, no. 2, pp. 363-370, 2017.

[45] S. Hughes, S. McBain, J. Dobson, and A. J. El Haj, "Selective activation of mechanosensitive ion channels using magnetic particles," Journal of the Royal Society Interface, vol. 5, no. 25, pp. 855-863, 2008.

[46] J.-H. Lee, J.-W. Kim, M. Levy et al., "Magnetic nanoparticles for ultrafast mechanical control of inner ear hair cells," ACS Nano, vol. 8, no. 7, pp. 6590-6598, 2014.

[47] A. Tay, A. Kunze, C. Murray, and D. Di Carlo, "Induction of calcium influx in cortical neural networks by nanomagnetic forces," ACS Nano, vol. 10, no. 2, pp. 2331-2341, 2016.

[48] N. Wang, J. P. Butler, and D. E. Ingber, "Mechanotransduction across the cell surface and through the cytoskeleton," Science, vol. 260, no. 5111, pp. 1124-1127, 1993.

[49] F. Chowdhury, S. Na, D. Li et al., "Material properties of the cell dictate stress-induced spreading and differentiation in embryonic stem cells," Nature Materials, vol. 9, pp. 82-88, 2010.

[50] M. H. Cho, E. J. Lee, M. Son et al., "A magnetic switch for the control of cell death signalling in in vitro and in vivo systems," Nature Materials, vol. 11, no. 12, pp. 1038-1043, 2012. 
[51] K. Perica, A. Tu, A. Richter, J. G. Bieler, M. Edidin, and J. P. Schneck, "Magnetic field-induced t cell receptor clustering by nanoparticles enhances $\mathrm{t}$ cell activation and stimulates antitumor activity," ACS Nano, vol. 8, no. 3, pp. 2252-2260, 2014.

[52] J. Lee, E. Kim, M. Cho et al., "Artificial control of cell signaling and growth by magnetic nanoparticles," Angewandte Chemie, vol. 122 , no. 33 , pp. 5834-5838, 2010.

[53] R. J. Mannix, S. Kumar, F. Cassiola et al., "Nanomagnetic actuation of receptor-mediated signal transduction," Nature Nanotechnology, vol. 3, no. 1, pp. 36-40, 2008.

[54] K. Maier-Hauff, R. Rothe, R. Scholz et al., "Intracranial thermotherapy using magnetic nanoparticles combined with external beam radiotherapy: results of a feasibility study on patients with glioblastoma multiforme," Journal of Neuro-Oncology, vol. 81, no. 1, pp. 53-60, 2007.

[55] K. Maier-Hauff, F. Ulrich, D. Nestler et al., "Efficacy and safety of intratumoral thermotherapy using magnetic iron-oxide nanoparticles combined with external beam radiotherapy on patients with recurrent glioblastoma multiforme," Journal of Neuro-Oncology, vol. 103, no. 2, pp. 317-324, 2011.

[56] M. Johannsen, U. Gneveckow, L. Eckelt et al., "Clinical hyperthermia of prostate cancer using magnetic nanoparticles: presentation of a new interstitial technique," International Journal of Hyperthermia, vol. 21, no. 7, pp. 637-647, 2005.

[57] M.-H. Kim, I. Yamayoshi, S. Mathew, H. Lin, J. Nayfach, and S. I. Simon, "Magnetic nanoparticle targeted hyperthermia of cutaneous Staphylococcus aureus infection," Annals of Biomedical Engineering, vol. 41, no. 3, pp. 598-609, 2013.

[58] D. Rodrigues, M. Bañobre-López, B. Espiña, J. Rivas, and J. Azeredo, "Effect of magnetic hyperthermia on the structure of biofilm and cellular viability of a food spoilage bacterium," Biofouling, vol. 29, no. 10, pp. 1225-1232, 2013.

[59] R. Hergt, R. Hiergeist, M. Zeisberger et al., "Magnetic properties of bacterial magnetosomes as potential diagnostic and therapeutic tools," Journal of Magnetism and Magnetic Materials, vol. 293, no. 1, pp. 80-86, 2005.

[60] R.-T. Liu, J. Liu, J.-Q. Tong et al., "Heating effect and biocompatibility of bacterial magnetosomes as potential materials used in magnetic fluid hyperthermia," Progress in Natural Science: Materials International, vol. 22, no. 1, pp. 31-39, 2012.

[61] S. Mannucci, L. Ghin, G. Conti et al., "Magnetic nanoparticles from Magnetospirillum gryphiswaldense increase the efficacy of thermotherapy in a model of Colon Carcinoma," PLoS ONE, vol. 9, no. 10, Article ID 0108959, 2014.

[62] E. Alphandéry, S. Faure, O. Seksek, F. Guyot, and I. Chebbi, "Chains of magnetosomes extracted from AMB-1 magnetotactic bacteria for application in alternative magnetic field cancer therapy," ACS Nano, vol. 5, no. 8, pp. 6279-6296, 2011.

[63] E. Alphandéry, F. Guyot, and I. Chebbi, "Preparation of chains of magnetosomes, isolated from Magnetospirillum magneticum strain AMB-1 magnetotactic bacteria, yielding efficient treatment of tumors using magnetic hyperthermia," International Journal of Pharmaceutics, vol. 434, no. 1-2, pp. 444-452, 2012.

[64] C. Chen, L. Chen, Y. Yi, C. Chen, L.-F. Wu, and T. Song, "Killing of Staphylococcus aureus via magnetic hyperthermia mediated by magnetotactic bacteria," Applied and Environmental Microbiology, vol. 82, no. 7, pp. 2219-2226, 2016.

[65] R. Yang, Q. Tang, F. Miao et al., "Inhibition of heat-shock protein 90 sensitizes liver cancer stem-like cells to magnetic hyperthermia and enhances anti-tumor effect on hepatocellular carcinoma-burdened nude mice," International Journal of Nanomedicine, vol. 10, pp. 7345-7358, 2015.
[66] K. A. Court, H. Hatakeyama, S. Y. Wu et al., "HSP70 inhibition synergistically enhances the effects of magnetic fluid hyperthermia in ovarian cancer," Molecular Cancer Therapeutics, vol. 16, no. 5, pp. 966-976, 2017.

[67] R. Hergt and S. Dutz, "Magnetic particle hyperthermiabiophysical limitations of a visionary tumour therapy," Journal of Magnetism and Magnetic Materials, vol. 311, no. 1, pp. 187-192, 2007.

[68] C. Sanchez, D. El Hajj Diab, V. Connord et al., "Targeting a Gprotein-coupled receptor overexpressed in endocrine tumors by magnetic nanoparticles to induce cell death," ACS Nano, vol. 8, no. 2, pp. 1350-1363, 2014.

[69] L. Asín, M. R. Ibarra, A. Tres, and G. F. Goya, "Controlled cell death by magnetic hyperthermia: Effects of exposure time, field amplitude, and nanoparticle concentration," Pharmaceutical Research, vol. 29, no. 5, pp. 1319-1327, 2012.

[70] M. Domenech, I. Marrero-Berrios, M. Torres-Lugo, and C. Rinaldi, "Lysosomal membrane permeabilization by targeted magnetic nanoparticles in alternating magnetic fields," ACS Nano, vol. 7, no. 6, pp. 5091-5101, 2013.

[71] A. Villanueva, P. De La Presa, J. M. Alonso et al., "Hyperthermia hela cell treatment with silica-coated manganese oxide nanoparticles," Journal of Physical Chemistry C, vol. 114, no. 5, pp. 1976-1981, 2010.

[72] V. Grazú, A. M. Silber, M. Moros et al., "Application of magnetically induced hyperthermia in the model protozoan Crithidia fasciculata as a potential therapy against parasitic infections," International Journal of Nanomedicine, vol. 7, pp. 5351-5360, 2012.

[73] A. Riedinger, P. Guardia, A. Curcio et al., "Subnanometer local temperature probing and remotely controlled drug release based on Azo-functionalized iron oxide nanoparticles," Nano Letters, vol. 13, no. 6, pp. 2399-2406, 2013.

[74] J. T. Dias, M. Moros, P. Del Pino, S. Rivera, V. Grazú, and J. M. De La Fuente, "DNA as a molecular local thermal probe for the analysis of magnetic hyperthermia," Angewandte Chemie International Edition, vol. 52, no. 44, pp. 11526-11529, 2013.

[75] H. Huang, S. Delikanli, H. Zeng, D. M. Ferkey, and A. Pralle, "Remote control of ion channels and neurons through magnetic-field heating of nanoparticles," Nature Nanotechnology, vol. 5, no. 8, pp. 602-606, 2010.

[76] R. Chen, G. Romero, M. G. Christiansen, A. Mohr, and P. Anikeeva, "Wireless magnetothermal deep brain stimulation," Science, vol. 347, no. 6229, pp. 1477-1480, 2015.

[77] S. A. Stanley, J. E. Gagner, S. Damanpour, M. Yoshida, J. S. Dordick, and J. M. Friedman, "Radio-wave heating of iron oxide nanoparticles can regulate plasma glucose in mice," Science, vol. 336, no. 6081, pp. 604-608, 2012.

[78] S. A. Stanley, J. Sauer, R. S. Kane, J. S. Dordick, and J. M. Friedman, "Remote regulation of glucose homeostasis in mice using genetically encoded nanoparticles," Nature Medicine, vol. 21, no. 1, pp. 92-98, 2015.

[79] S. A. Stanley, L. Kelly, K. N. Latcha et al., "Bidirectional electromagnetic control of the hypothalamus regulates feeding and metabolism," Nature, vol. 531, no. 7596, pp. 647-650, 2016.

[80] A. Gupta, R. S. Kane, and D.-A. Borca-Tasciuc, "Local temperature measurement in the vicinity of electromagnetically heated magnetite and gold nanoparticles," Journal of Applied Physics, vol. 108, no. 6, Article ID 064901, 2010.

[81] R. Hergt, W. Andrae, C. G. d'Ambly et al., "Physical limits of hyperthermia using magnetite fine particles," IEEE Transactions on Magnetics, vol. 34, no. 5, pp. 3745-3754, 1998. 
[82] P. Keblinski, D. G. Cahill, A. Bodapati, C. R. Sullivan, and T. A. Taton, "Limits of localized heating by electromagnetically excited nanoparticles," Journal of Applied Physics, vol. 100, no. 5, Article ID 054305, 2006.

[83] M. Meister, "Physical limits to magnetogenetics," eLife, vol. 5, 2016.

[84] C. L. Dennis and R. Ivkov, "Physics of heat generation using magnetic nanoparticles for hyperthermia," International Journal of Hyperthermia, vol. 29, no. 8, pp. 715-729, 2013.

[85] J. Carrey, V. Connord, and M. Respaud, "Ultrasound generation and high-frequency motion of magnetic nanoparticles in an alternating magnetic field: toward intracellular ultrasound therapy?" Applied Physics Letters, vol. 102, no. 23, Article ID 232404, 2013

[86] T. Saliev, L. B. Feril Jr., K. Ogawa et al., "Induction of apoptosis in U937 cells by using a combination of bortezomib and lowintensity ultrasound," Medical Science Monitor, vol. 22, pp. 5049-5057, 2016

[87] M. Ivone, C. Pappalettere, A. Watanabe, and K. Tachibana, "Study of cellular response induced by low intensity ultrasound frequency sweep pattern on myelomonocytic lymphoma U937 cells," Journal of Ultrasound, vol. 19, no. 3, pp. 167-174, 2016.

[88] N. Hallali, P. Clerc, D. Fourmy, V. Gigoux, and J. Carrey, "Influence on cell death of high frequency motion of magnetic nanoparticles during magnetic hyperthermia experiments," Applied Physics Letters, vol. 109, no. 3, Article ID 032402, 2016.

[89] T. Yue, X. Zhang, and F. Huang, "Molecular modeling of membrane responses to the adsorption of rotating nanoparticles: promoted cell uptake and mechanical membrane rupture," Soft Matter, vol. 11, no. 3, pp. 456-465, 2015.

[90] S. Bulut, W. M. Waites, and J. R. Mitchell, "Effects of combined shear and thermal forces on destruction of Microbacterium lacticum," Applied and Environmental Microbiology, vol. 65, no. 10, pp. 4464-4469, 1999.

[91] S. Sahoo, K. K. Rao, and G. K. Suraishkumar, "Reactive oxygen species induced by shear stress mediate cell death in Bacillus subtilis," Biotechnology and Bioengineering, vol. 94, no. 1, pp. 118-127, 2006.

[92] X. Long, J. Ye, D. Zhao, and S.-J. Zhang, "Magnetogenetics: remote non-invasive magnetic activation of neuronal activity with a magnetoreceptor," Science Bulletin, vol. 60, no. 24, pp. 2107-2119, 2015.

[93] M. A. Wheeler, C. J. Smith, M. Ottolini et al., "Genetically targeted magnetic control of the nervous system," Nature Neuroscience, vol. 19, no. 5, pp. 756-761, 2016.

[94] M. Bernardini, A. Fiorio Pla, N. Prevarskaya, and D. Gkika, "Human transient receptor potential (TRP) channels expression profiling in carcinogenesis," International Journal of Developmental Biology, vol. 59, no. 7-9, pp. 399-406, 2015.

[95] A. Kondratskyi, K. Kondratska, R. Skryma, and N. Prevarskaya, "Ion channels in the regulation of apoptosis," Biochimica et Biophysica Acta - Biomembranes, vol. 1848, no. 10, pp. 2532-2546, 2015.

[96] K. Kunzelmann, "Ion channels in regulated cell death," Cellular and Molecular Life Sciences, vol. 73, no. 11-12, pp. 2387-2403, 2016.

[97] S. Dwivedi, M. A. Siddiqui, N. N. Farshori, M. Ahamed, J. Musarrat, and A. A. Al-Khedhairy, "Synthesis, characterization and toxicological evaluation of iron oxide nanoparticles in human lung alveolar epithelial cells," Colloids and Surfaces B: Biointerfaces, vol. 122, pp. 209-215, 2014.
[98] P. Wang, C. Chen, K. Zeng, W. Pan, and T. Song, "Magnetic nanoparticles trigger cell proliferation arrest of neuro-2a cells and ROS-mediated endoplasmic reticulum stress response," Journal of Nanoparticle Research, vol. 16, no. 11, 2014.

[99] S. Naqvi, M. Samim, M. Z. Abdin et al., "Concentration-dependent toxicity of iron oxide nanoparticles mediated by increased oxidative stress," International Journal of Nanomedicine, vol. 5, no. 1, pp. 983-989, 2010.

[100] L. Gao, J. Zhuang, L. Nie et al., "Intrinsic peroxidase-like activity of ferromagnetic nanoparticles," Nature Nanotechnology, vol. 2, no. 9, pp. 577-583, 2007.

[101] Z. Chen, J.-J. Yin, Y.-T. Zhou et al., "Dual enzyme-like activities of iron oxide nanoparticles and their implication for diminishing cytotoxicity," ACS Nano, vol. 6, no. 5, pp. 4001-4012, 2012.

[102] D.-M. Huang, J.-K. Hsiao, Y.-C. Chen et al., "The promotion of human mesenchymal stem cell proliferation by superparamagnetic iron oxide nanoparticles," Biomaterials, vol. 30, no. 22, pp. 3645-3651, 2009.

[103] M. Yu, S. Huang, K. J. Yu, and A. M. Clyne, "Dextran and polymer polyethylene glycol (PEG) coating reduce both 5 and $30 \mathrm{~nm}$ iron oxide nanoparticle cytotoxicity in 2D and 3D cell culture," International Journal of Molecular Sciences, vol. 13, no. 5, pp. 5554-5570, 2012.

[104] V. Connord, P. Clerc, N. Hallali et al., "Real-time analysis of magnetic hyperthermia experiments on living cells under a confocal microscope," Small, vol. 11, no. 20, pp. 2437-2445, 2015.

[105] J.-E. Bae, M.-I. Huh, B.-K. Ryu et al., "The effect of static magnetic fields on the aggregation and cytotoxicity of magnetic nanoparticles," Biomaterials, vol. 32, no. 35, pp. 9401-9414, 2011.

[106] H. L. Jia, C. Wang, Y. Li et al., "Combined effects of $50 \mathrm{~Hz}$ magnetic field and magnetic nanoparticles on the proliferation and apoptosis of PC12 cells," Biomedical and Environmental Sciences, vol. 27, no. 2, pp. 97-105, 2014.

[107] A. Pal, A. Singh, T. C. Nag, P. Chattopadhyay, R. Mathur, and S. Jain, "Iron oxide nanoparticles and magnetic field exposure promote functional recovery by attenuating free radical-induced damage in rats with spinal cord transection," International Journal of Nanomedicine, vol. 8, pp. 2259-2272, 2013.

[108] J. Shin, C.-H. Yoo, J. Lee, and M. Cha, "Cell response induced by internalized bacterial magnetic nanoparticles under an external static magnetic field," Biomaterials, vol. 33, no. 22, pp. 56505657, 2012.

[109] R. J. Wydra, C. E. Oliver, K. W. Anderson, T. D. Dziubla, and J. Z. Hilt, "Accelerated generation of free radicals by iron oxide nanoparticles in the presence of an alternating magnetic field," RSC Advances, vol. 5, no. 24, pp. 18888-18893, 2015.

[110] V. Binhi, "Do naturally occurring magnetic nanoparticles in the human body mediate increased risk of childhood leukaemia with EMF exposure?" International Journal of Radiation Biology, vol. 84, no. 7, pp. 569-579, 2008.

[111] V. N. Binhi and D. S. Chernavskii, "Stochastic dynamics of magnetosomes in cytoskeleton," Europhysics Letters, vol. 70, no. 6, pp. 850-856, 2005.

[112] R. D. Montoya, "Magnetic fields, radicals and cellular activity," Electromagnetic Biology and Medicine, pp. 1-12, 2016.

[113] Q. L. Zhao, Y. Fujiwara, and T. Kondo, "Mechanism of cell death induction by nitroxide and hyperthermia," Free Radical Biology \& Medicine, vol. 40, no. 7, pp. 1131-1143, 2006.

[114] T. Yoshikawa, S. Kokura, K. Tainaka et al., "The role of active oxygen species and lipid peroxidation in the antitumor effect of hyperthermi," Cancer Research, vol. 53, no. 10, pp. 2326-2329, 1993. 

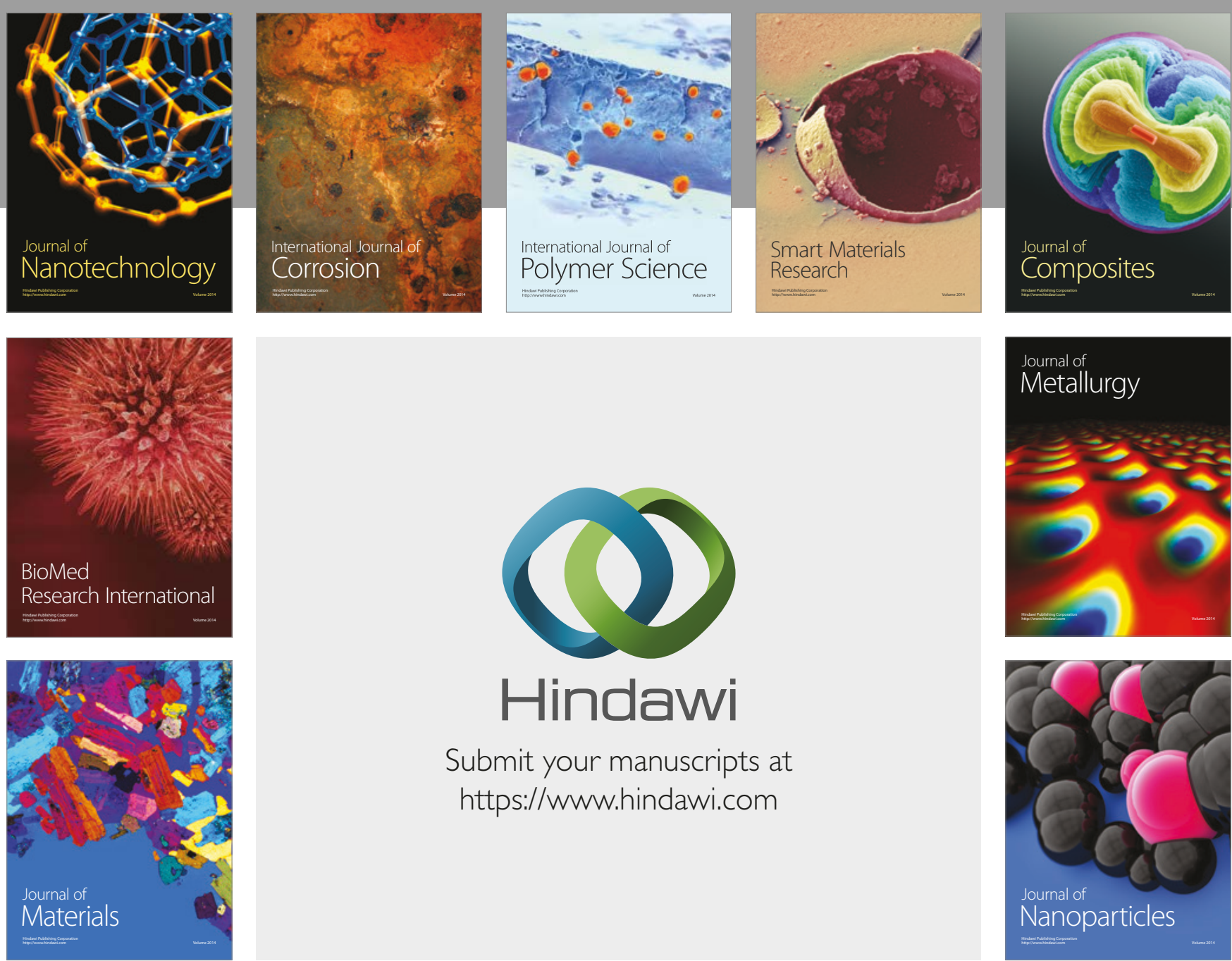

\section{Hindawi}

Submit your manuscripts at

https://www.hindawi.com
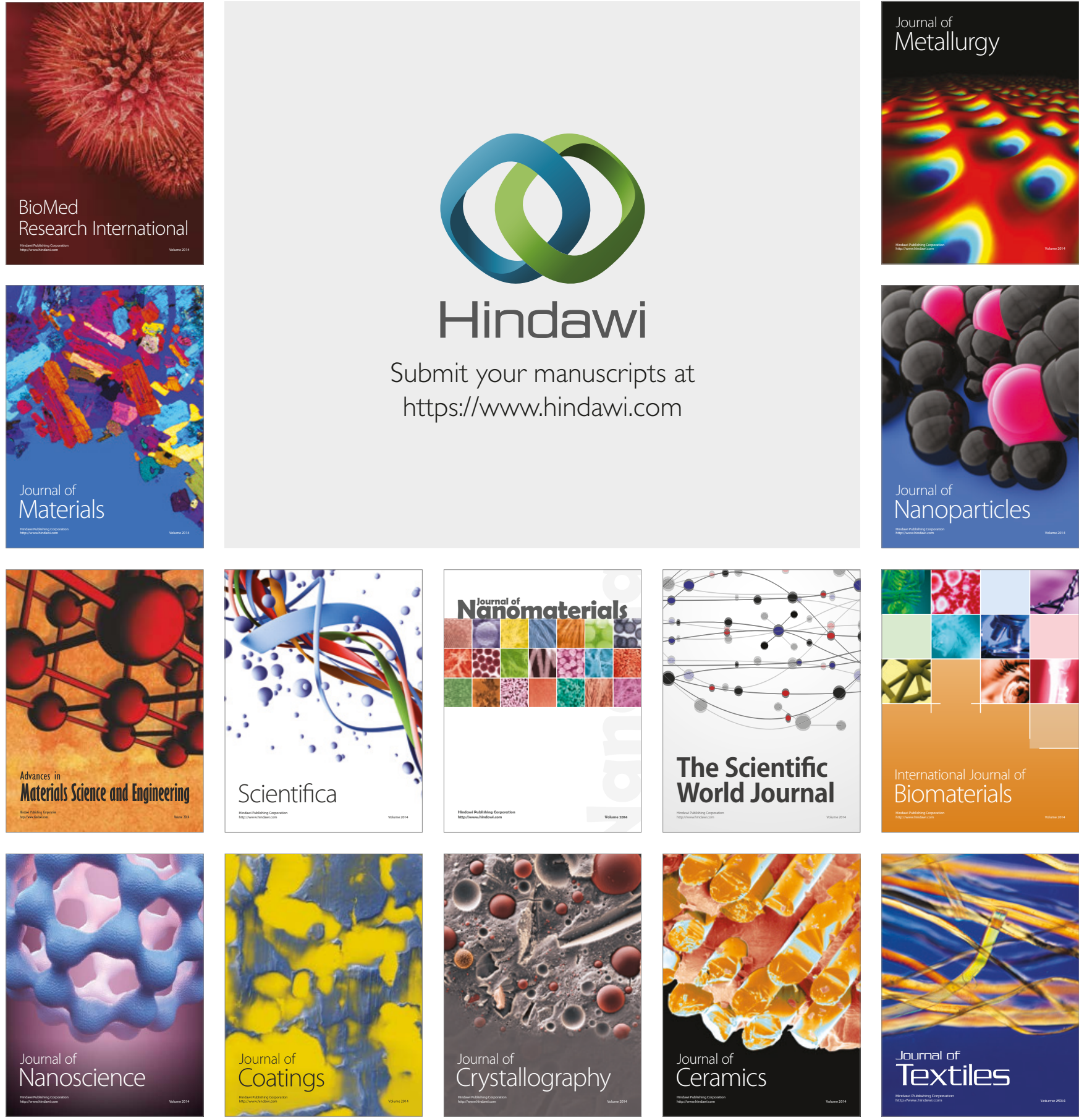

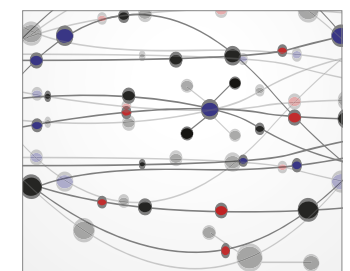

The Scientific World Journal
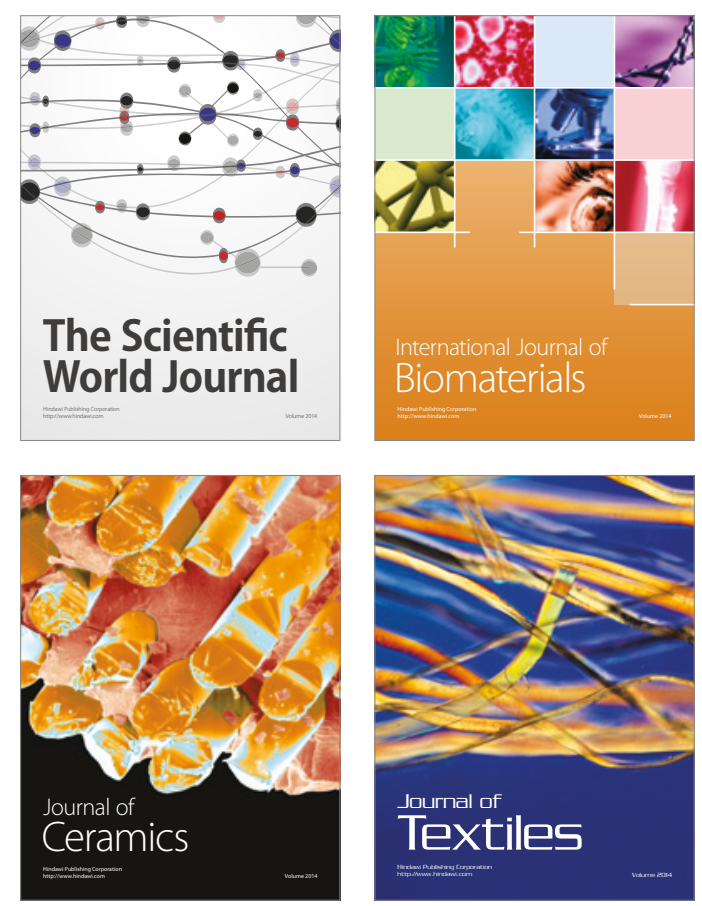